\title{
VIRULENCE PROFILE OF TEN Paracoccidioides brasiliensis ISOLATES. ASSOCIATION WITH MORPHOLOGIC AND GENETIC PATTERNS
}

\author{
Cilmery S. KUROKAWA(1), Catalina R. LOPES(2), Maria F. SUGIZAKI(3), Eiko E. KURAMAE(2), Marcello F. FRANCO(4) \& Maria T. S. PERAÇOLI(3)
}

\begin{abstract}
SUMMARY
Ten isolates of Paracoccidioides brasiliensis were examined for differences in virulence in outbred mice intravenously inoculated with the fungus, associated with mycelial morphology, and genetic patterns measured by random amplified polymorphic DNA (RAPD). Virulence was evaluated by viable yeast cell recovery from lungs and demonstration of histopathologic lesions in different organs. The results showed that the isolates presented four virulence degrees: high virulence, intermediate, low and non-virulence. RAPD clustered the isolates studied in two main groups with $56 \%$ of genetic similarity. Strains with low virulence, $\mathrm{Pb} 265$ or the non-virulent, Pb192, showed glabrous/cerebriform morphology and high genetic similarity (98.7\%) when compared to the other isolates studied. The same was observed with Bt79 and Bt83 that shared 96\% genetic similarity, cottony colonies and high virulence. The RAPD technique could only discriminate $P$. brasiliensis isolates according to glabrous/cerebriform or cottony colonies, and also high from low virulence strains. Isolates with intermediate virulence such as $\mathrm{Pb} 18, \mathrm{~Pb} 18 \mathrm{~B} 6, \mathrm{Bt} 32$ and $\mathrm{Bt} 56$ showed variability in their similarity coefficient suggesting that RAPD was able to detect genetic variability in this fungal specie. Virulence profile of $P$. brasiliensis demonstrated that both mycelial morphologic extreme phenotypes may be associated with fungal virulence and their in vitro subculture time. Thus, RAPD technique analysis employed in association with virulence, morphologic and immunologic aspects might prove adequate to detect differences between P. brasiliensis isolates.
\end{abstract}

KEYWORDS: Antibodies; Colony morphology; Paracoccidioides brasiliensis; RAPD; Virulence.

\section{INTRODUCTION}

Paracoccidioides brasiliensis the etiologic agent of paracoccidioidomycosis ( $\mathrm{PCM}$ ), is a thermally dimorphic pathogenic fungus. This mycosis is endemic in South America occurring from Central America to Argentina ${ }^{33}$. The different clinical forms of the disease, and the occurrence of paracoccidioidomycosis-infection, may be due to host related factors as well as to characteristics of the infecting agent, mainly virulence ${ }^{8}$.

Animal models have been very useful for studying host-parasite interactions in PCM, and have revealed that different $P$. brasiliensis isolates may vary in virulence ${ }^{4,12,27}$, a fact that might explains the different clinical manifestation of the disease.

Differences in virulence of $P$. brasiliensis isolates in mice have also been reported $d^{4,14,27}$, and associated with the amount of $\alpha-1,3$ glucan in the fungal cell wall ${ }^{24}$. Virulence is also influenced by in vitro passage and storage of the isolates ${ }^{4,22}$.

Some studies employed to analyze growth curves, and morphology of yeasts have shown variability between $P$. brasiliensis strains, but no association with pathogenicity has been observed ${ }^{12,13}$. Another aspect that has been studied in connection with virulence is mycelial growth morphology. Cottonous morphology appears to be related to virulent strain while glabrous morphology is associated with low virulence strains $^{25}$

Random Amplified Polymorphic DNA (RAPD) analysis has also become very useful for microbial strain identification, and has been successfully used to detect genomic variations between fungal isolates such as Aspergillus fumigatus ${ }^{1,19}$, Histoplasma capsulatum ${ }^{35}$ and $P$. brasiliensis $^{31}$.

RAPD analysis of $P$. brasiliensis has been used for clustering strains by geographic area ${ }^{5,11}$, as a means to clarify PCM pathogenesis ${ }^{26}$ and also, to correlate RAPD pattern with virulence ${ }^{18}$. Taking these facts together, we investigated virulence profile in ten $P$. brasiliensis isolates using different parameters and exploring the relationship between their phenotypes and RAPD pattern.

\section{MATERIAL AND METHODS}

P. brasiliensis isolates: Ten isolates of $P$. brasiliensis were employed, eight obtained from patients with paracoccidioidomycosis, one isolated from a hamster inoculated with armadillo visceral organ

(1) Departamento de Pediatria, Faculdade de Medicina, UNESP, Botucatu, São Paulo, SP, Brasil.

(2) Departamento de Genética, Instituto de Biociências, UNESP, Botucatu, São Paulo, SP, Brasil.

(3) Departamento de Microbiologia e Imunologia, Instituto de Biociências, UNESP, Botucatu, São Paulo, SP, Brasil.

(4) Departamento de Patologia, UNIFESP, São Paulo, SP, Brasil.

Correspondence to: Dra Cilmery Suemi Kurokawa, Departamento de Pediatria, Faculdade de Medicina de Botucatu/UNESP, Rubião Júnior s/n, 18618-000 Botucatu, São Paulo, Brazil. Phone: 5514 3811-6274. E-mail: kurokawa@fmb.unesp.br 
KUROKAWA, C.S.; LOPES, C.R.; SUGIZAKI, M.F.; KURAMAE, E.E.; FRANCO, M.F. \& PERAÇOLI, M.T.S. - Virulence profile of ten Paracoccidioides brasiliensis isolates. Association with morphologic and genetic patterns. Rev. Inst. Med. trop. S. Paulo, 47(5): 257-262, 2005.

homogenates $(\mathrm{Pb}-\mathrm{T})$ and another recovered from $\mathrm{C} 57 \mathrm{~B} 1 / .6$ mice infected with $\mathrm{Pb} 18$ (Pb18B6) (Table 1). All isolates were maintained on 2\% Glucose, $1 \%$ Peptone and $0.5 \%$ Yeast Extract medium (GPY medium) at $35{ }^{\circ} \mathrm{C}$ from time of isolation and were sub-cultured to fresh media every 15 days.

Colony morphology: Colony morphology of the ten isolates was evaluated by observation of giant colonies in their mycelial form. Each isolate obtained from a 6 day-old culture in GPY medium at $35^{\circ} \mathrm{C}$ was plated on the central area of three $220 \times 100 \mathrm{~mm}$ Petri dishes with Potato dextrose agar (PDA) with aid of a platinum loop that permits an inoculation around $3 \mathrm{~mm}$ in diameter. Plates were incubated at $25-$ $28^{\circ} \mathrm{C}$ for eight weeks, and colonies were examined for shape, size, texture and presence of pigment.

Animals: Groups of 10-week-old male outbred swiss mice were provided from the animal facility of Botucatu Campus, São Paulo State University, for this study. The animals were provided with acidified water and sterilized pellet food ad libitum.

Virulence studies: Groups of 10 mice each were inoculated by the intravenous (iv) route with $2 \times 10^{6}$ yeast cells from a 6 day-old culture of P. brasiliensis isolates: $\mathrm{Pb} 18, \mathrm{~Pb} 18 \mathrm{~B} 6, \mathrm{Bt} 32, \mathrm{Bt56}, \mathrm{Bt79}$, $\mathrm{Bt83}, \mathrm{Bt84}, \mathrm{Pb} 192, \mathrm{~Pb} 265$ and PbT. Fungus viability was determined by phase microscopy ${ }^{30}$ and it was always above $90 \%$. Four weeks postinfection animals were sacrificed and submitted to histopathologic study, recovery of viable fungi from lungs, and measurement of specific antibody levels.

Sacrifice and histopathology: Each animal was sacrificed by ether anesthesia and cardiac puncture exsanguination. Blood was collected and tissue samples were taken from lungs, liver, spleen, kidney, and adrenal gland. Blood samples were allowed to clot and the supernatant sera centrifuged and stored at $-20{ }^{\circ} \mathrm{C}$. Tissue samples were fixed in formalin, and embedded in paraffin, cut into $4 \mu \mathrm{m}$ sections and stained with hematoxylin-eosin.

Recovery of viable yeast from lungs: The number of viable fungi in infected mouse lungs was determined by counting colony forming units (CFUs). At sacrifice, the right lungs from all animals were aseptically removed weighed and individually homogenized in $1.5 \mathrm{~mL}$ of sterile phosphate buffer saline $\mathrm{pH} 7.2$ (PBS) in a tissue grinder. Aliquots of $100 \mu \mathrm{L}$ of each homogenate were plated by triplicate onto plates with brain heart infusion (BHI) agar (Difco Laboratories, Detroit, Mich.) supplemented with $4 \%(\mathrm{v} / \mathrm{v})$ normal horse serum and 5\% P. brasiliensis 192 culture filtrate, the latter constituting the source of growth-promoting factors ${ }^{28}$. Plates were incubated at $35^{\circ} \mathrm{C}$ and colonies were counted daily until there were no further increases. Results were expressed as logarithmic values of $\mathrm{CFU} / \mathrm{g}$ of lung.

P. brasiliensis antigen: Culture filtrate antigen $(\mathrm{PbAg})$ was prepared using a pool of 6-day-old yeast cells from the ten $P$. brasiliensis isolates, cultured in Casal's medium ${ }^{7}$ at $35{ }^{\circ} \mathrm{C}$. Each culture filtrate was centrifuged separately at $10,000 \mathrm{~g}$ for $30 \mathrm{~min}$ at $4{ }^{\circ} \mathrm{C}$, concentrated to a $10 \mathrm{~mL}$-volume and dialyzed against PBS. Then the ten culture filtrate were pooled, filtered through a $0.22 \mu \mathrm{m}$ Millipore membrane, and submitted to sterility tests. Protein concentration was determined by the method of LOWRY et al. ${ }^{16}$.
Humoral immunity: Specific antibody levels to P. brasiliensis were measured by the enzyme linked immunosorbent assay (ELISA) as described previously ${ }^{17}$. All sera were tested in two-fold dilutions and each $\mathrm{PbAg}$ was used at $20 \mu \mathrm{g}$ protein/mL. Goat-anti-mouse total immunoglobulin peroxidase conjugate (Sigma, Chemical Co, St Louis, Mo, USA) was used in all experiments. As controls, antibody titers of sera from non-infected mice, housed under identical conditions as the infected animals, were also determined. Average optical density obtained with control mice sera at 1:16 dilution was considered the reaction cut off value. Optical densities for each dilution of the experimental sera were compared with control values. Sample titers were expressed as the reciprocal of the highest serum dilution with absorbance higher than cut off value.

DNA-preparation: DNA was prepared by PAN \& COLE' ${ }^{21}$ method to obtain protoplast cell. After cell wall digestion, protoplast was ressuspended in buffer lyses, $50 \mathrm{mM}$ Tris-HCL (Sigma) and $20 \mathrm{mM}$ EDTA pH 7.5 (Sigma), $250 \mu \mathrm{L}$ SDS $10 \%, 300 \mu \mathrm{L}$ Proteinase K (10 $\mathrm{mg} / \mathrm{mL}$ ) (Sigma) and incubated at $65{ }^{\circ} \mathrm{C}$ for $30 \mathrm{~min}$. Before DNA purification, protoplast cells buffer lyses were incubated on ice with $5 \mathrm{M}$ potassium acetate for $60 \mathrm{~min}$, and then treated with RNAse. DNA was then purified with phenol, phenol:clorophorm, clorophorm, isopropanol, and $70 \%$ ethanol; DNA was then resuspended in $10 \mathrm{mM}$ Tris- $\mathrm{HCl}$ plus $1 \mathrm{mM}$ pH8 EDTA and stored at $-20{ }^{\circ} \mathrm{C}$.

RAPD analysis: Seventeen 10-bp primers (Operon Biotechnology) namely, OPB05, OPB07, OPB8, OPB10, OPB11, OPB12, OPB14, OPB15, OPB17, OPB18, OPG13, OPP02, OPP14, Opn13, Opr09, OPR08, and OPR07 were used for the RAPD assay ${ }^{10,34}$. The DNA amplification reactions were performed in a $13 \mu \mathrm{L}$ system that consisted of $5 \mathrm{ng}$ genomic $P$. brasiliensis DNA; $1.3 \mu \mathrm{L}$ of $10 \mathrm{x}$ Taq buffer $(200$ $\mathrm{mM}$ Tris-HCl; $\mathrm{pH} 8.4 ; 500 \mathrm{mM} \mathrm{KCl}) ; 2.5 \mathrm{mM}$ of each deoxynucleotide triphosphate; $3 \mu \mathrm{L}$ of primer ( $5 \mathrm{ng} / \mu \mathrm{L}$ ); $1 \mathrm{U}$ Taq DNA polymerase (Gibco, BRL, Geisthersburg, MD, USA); $1.5 \mathrm{mM}$ of $\mathrm{MgCl}_{2} ; 1.04 \mu \mathrm{L}$ nonacetylated bovine serum albumin $(10 \mathrm{mg} / \mathrm{mL})$ (New England Biolabs, Beverly, MA, USA) and water to make up the volume to $13 \mu \mathrm{L}$. The reaction underwent 40 cycles in an automatic thermal cycler (MJ Research PT 100 Mini-Cycler); each cycle consisting of 1 min at $92{ }^{\circ} \mathrm{C}$ for denaturation, $1 \mathrm{~min}$ at $35{ }^{\circ} \mathrm{C}$ for annealing, $2 \mathrm{~min}$ at $72{ }^{\circ} \mathrm{C}$ for elongation. Randomly amplified products underwent electrophoresis analysis on a $1.4 \%$ agarose gel and were developed with ethidium bromide staining.

Statistical analysis: The RAPD pattern from each isolate was analyzed by NTSYS 1.7 software (Numerical Taxonomy and Multivariate Analysis System, NY, USA), using the Jaccard coefficient ${ }^{23}$. The dendogram was derived from the distance matrix by the Unweighted Pair-Group Method Arithmetic Average (UPGMA). Number of CFU/g of lung was transformed into logarithmic units and analyzed by one-way analysis of variance (ANOVA) followed by multiple comparisons by the Tukey test. Antibody level from sera was analyzed by the Kruskal-Wallis test. Correlation between CFU/g of lung and antibody levels was done by linear correlation. Significance was considered at $\mathrm{p}<0.05$.

\section{RESULTS}

Colony morphology: Phenotypes were distinguished by differences 
KUROKAWA, C.S.; LOPES, C.R.; SUGIZAKI, M.F.; KURAMAE, E.E.; FRANCO, M.F. \& PERAÇOLI, M.T.S. - Virulence profile of ten Paracoccidioides brasiliensis isolates. Association with morphologic and genetic patterns. Rev. Inst. Med. trop. S. Paulo, 47(5): 257-262, 2005.

in colony shape, texture, and presence of pigment. The colonies of $P$. brasiliensis isolates presented two distinct phenotypes which could be maintained and stabilized in subculture. The first was present in $\mathrm{Pb} 18$, $\mathrm{Pb} 18 \mathrm{~B} 6, \mathrm{Bt} 32, \mathrm{Bt79}, \mathrm{Bt} 83$ and Bt84 isolates, all of which showed cottony phenotype with colonies adherent to the medium, white cottonlike surface with or without central fissures and the undersides were brownish in color. In the second phenotype, colony color was creamy, wrinkled and folded, aerial hyphae were rare, and the colonies never became floccose or cottony. This type was named glabrous phenotype and included $\mathrm{Bt56}, \mathrm{Pb} 192, \mathrm{~Pb} 265$ and $\mathrm{PbT}$ isolates (Fig. 1).

Recovery of viable $\boldsymbol{P}$. brasiliensis from lungs: Yeast cells counts (CFUs) in the lungs of mice inoculated with the different $P$. brasiliensis isolates revealed that the infection varied according to the isolate employed. The ten isolates showed four different pathogenic degrees of virulence according to number of viable fungal units recovered from infected mouse lung tissue: a) high virulence was attributed to Bt79, $\mathrm{Bt83}$, and Bt84, with significantly higher CFU values than all the other isolates; b) intermediate virulence to $\mathrm{Bt} 56, \mathrm{Bt} 32, \mathrm{~Pb} 18$, and Pb18B6; c) low virulence to $\mathrm{Pb} 265$ and $\mathrm{PbT}$; and d) non-virulence to $\mathrm{Pb} 192$ only (Table 1). There was no difference in the virulence profile between $\mathrm{Pb} 18$ isolate sub-cultured long term in vitro in our laboratory and $\mathrm{Pb} 18 \mathrm{~B} 6$ originating from $\mathrm{Pb} 18$ recovered from $\mathrm{C} 57 \mathrm{Bl} / 6$ infected mice.

Histopathological studies: Differences in virulence could also be observed in the histopathologic analysis. Seven of the ten isolates studied induced lung lesions. Animals infected with Pb18B6, Bt32 and Bt56 had few lung lesions that covered less than $1 / 4$ of the histological section (Fig. 2 A). Mice inoculated with Bt84 and PbT had moderate lesions with $1 / 4$ to $1 / 2$ of the histological section involvement and those with $\mathrm{Pb} 18, \mathrm{~Pb} 192$ and $\mathrm{Pb} 265$ isolates did not have lung lesions. Mice infected with Bt79 and Bt83, classified as highly virulence isolates, presented extensive lung lesions that covered $2 / 3$ or the whole section (Fig. 2B). Hepatic lesions were only detected in animals infected with Bt79, Bt83, Bt84, and Bt56. In Bt56 infected mice, there were few hepatic lesions and no fungi were seen. Extensive spleen and adrenal gland lesions were only observed in Bt79 and Bt83 infected animals (Fig. 2C) with high virulence. Low or non-virulent isolates did not induce lesions upon infection.

Antibody levels: $P$. brasiliensis isolates elicited distinct serological profiles during infection (Table 1). Mice infected with Bt79, Bt83 and Bt84 had antibody titers more elevated in comparison to those inoculated with the other seven isolates, and significantly higher than those detected in mice infected with Pb192. In these animals antibodies were absent or very low, with titers ranging from 0 to 1 . Animals infected with intermediate and low virulence isolates had similar antibody levels (Table 1).

RAPD analysis: A total of 103 reproducible amplification products were sufficiently polymorphic to allow strain differentiation. Depending on primer, one to seven bands were separated, ranging in size from 0.25 to $4.5 \mathrm{~kb}$. RAPD analysis showed two groups with $56 \%$ genomic identity, group one clustered $\mathrm{Bt32}, \mathrm{Pb} 192, \mathrm{~Pb} 265, \mathrm{~Pb} 18, \mathrm{PbT}, \mathrm{Bt79}$, Bt83, Pb18B6 strains and group two Bt56 and Bt84 (Fig. 3). Group one was divided in two subgroups, the first had all isolates except $\mathrm{Pb} 18 \mathrm{~B} 6$ and the second subgroup corresponded to Pb18B6 alone. Genetic similarity between these two subgroups was about $88 \%$. First
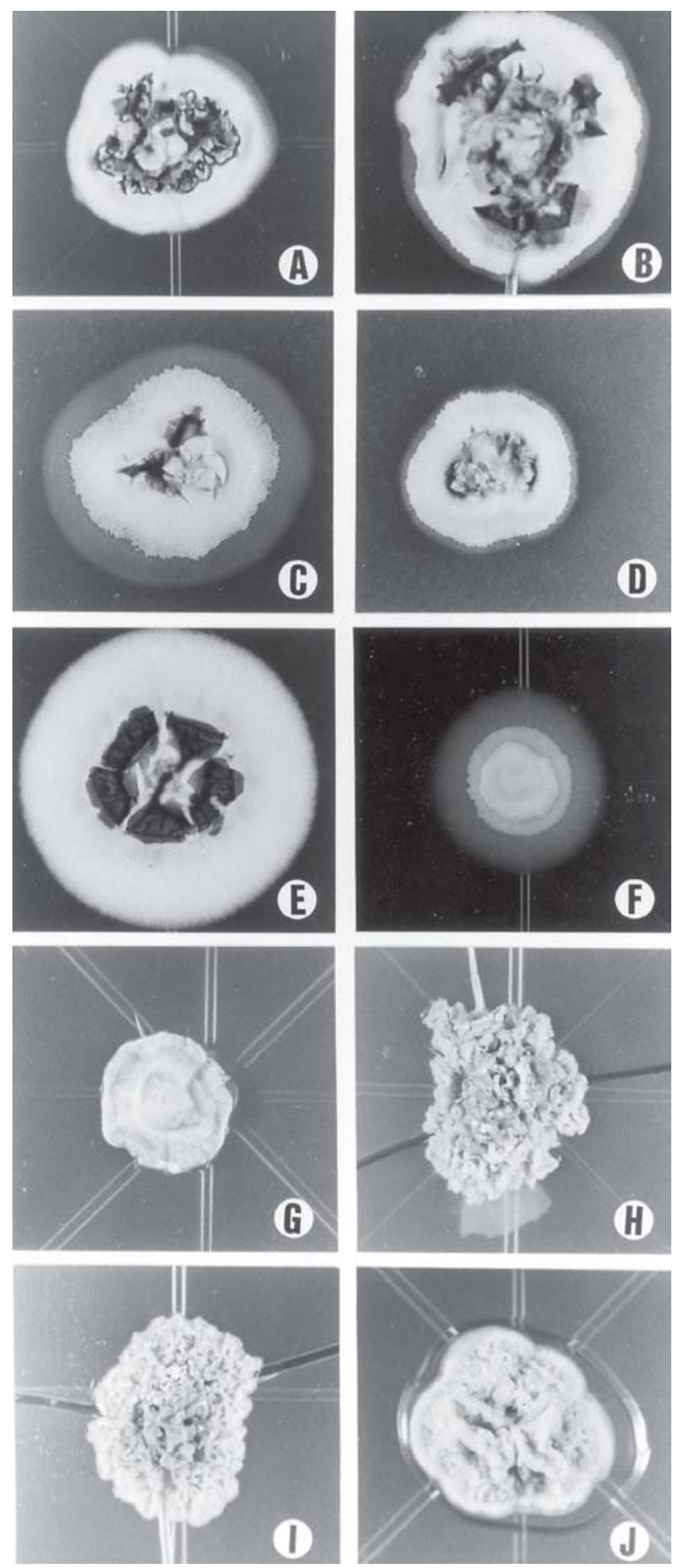

Fig.1 - Giant colonies from Paracoccidioides brasiliensis isolates cultured at $25{ }^{\circ} \mathrm{C}$ on Potato dextrose agar medium. A) Pb18, B) Pb18B6, C) Bt79, D) Bt83, E) Bt84, F) Bt32, G) Bt56, H) Pb192, I) Pb265, J) PbT.

subgroup isolates shared more than $90 \%$ of genetic similarity. Isolates $\mathrm{Pb} 265$ and $\mathrm{Pb} 192$ had a similarity coefficient of $98.7 \%$ and the mycelia colony form were glabrous/cerebriform with little difference in virulence pattern. Similarity of $96 \%$ was seen between Bt79 and Bt83, 

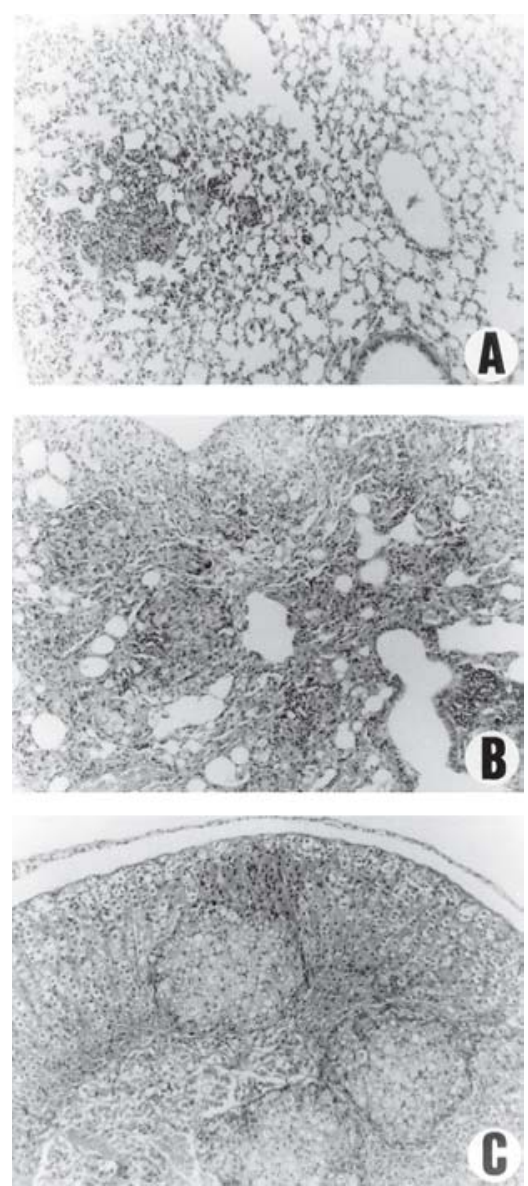

Fig. 2 - Lesion histopathology: (A) Lung tissue from mice infected with Bt32. (B) Lung tissue and $(\mathrm{C})$ adrenal gland from mice infected with Bt79 isolate. (HE - $100 \mathrm{x})$.

and mycelium morphology was similar for both isolates. Bt79 and Bt83 had cottony mycelia morphology with black central fissure and high virulence, demonstrated by extensive lesions in lungs, liver and adrenal gland of the infected mice.

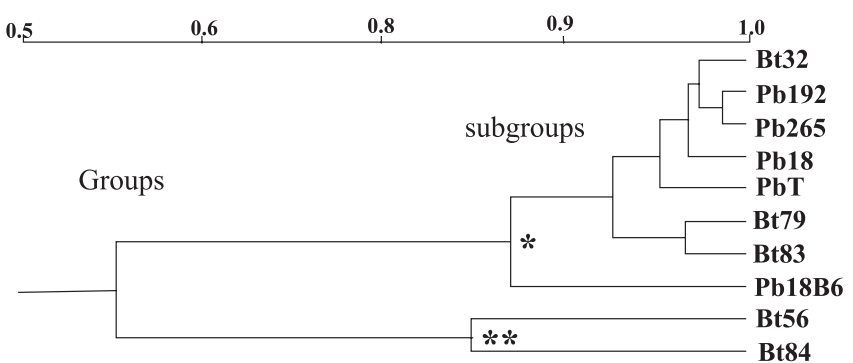

Fig. 3 - Dendogram of the relationship between Paracoccidioides brasiliensis isolates based on UPGMA clustering of matrix obtained by Jaccard coefficient. Note presence of two main groups: group $1(*)$ and group $2(* *)$

\section{DISCUSSION}

In this study we report the presence of phenotypic variations in $P$. brasiliensis isolates according to colonial morphology. The fungus was able to adopt either a glabrous or a cotton-like appearance. Many organisms have acquired the ability to vary their phenotype, generating variants within infectious populations as a mechanism designed to escape threatening environmental changes, such as host immunity development ${ }^{32}$. From the human isolates studied here, cotton-like colonies were more frequent than glabrous, as previously seen in other studies of the morphologic and physiologic features of $P$. brasiliensis isolates ${ }^{25}$.

Virulence of the ten fungal isolates as determined by both, number of viable fungi recovered from infected mouse lung tissues and histopathologic analysis were shown to be associated suggesting their efficiency in determining virulence of $P$. brasiliensis isolates. According to SINGER VERMES et al. ${ }^{29}$ estimation of the number of viable fungi in infected mouse organs by CFUs count is one of the most direct and trustworthy methods to assess severity of the disease. Fungal isolates Bt79, Bt83 and Bt84 which presented the cottony phenotype were classified as highly virulent strains as based on the high number of yeast cells, recovered from the lungs (5.04 to $6.10 \mathrm{log}$ CFUs/g), and also, on the isolates capacity to disseminate to extrapulmonary organs (liver and spleen), leading to extensive granulomatous lesions. Thus, the degree of virulence was inferred from disease severity in the mice.

Table 1

Comparative characteristics and degree of infection between 10 Paracoccidioides brasiliensis isolates

\begin{tabular}{|c|c|c|c|c|c|}
\hline Isolate & Morphology & $\begin{array}{l}\text { LogCFU/g lung tissue } \\
\quad(\text { mean } \pm \text { SD })\end{array}$ & Virulence & Antibody titer & $\begin{array}{l}\text { Subculturing } \\
\text { time (years) }\end{array}$ \\
\hline $\mathrm{Pb} 18$ & Cottony & $2.05 \pm 0.41^{*}$ & Intermediate & $48(8-128)$ & $>30$ \\
\hline $\mathrm{Pb} 18 / \mathrm{B} 6$ & Cottony & $2.60 \pm 0.46 *$ & Intermediate & $48(8-128)$ & 3 \\
\hline Bt 32 & Cottony & $2.47 \pm 0.50 *$ & Intermediate & $12(4-64)$ & 11 \\
\hline Bt 56 & Glabrous & $3.12 \pm 0.89 *$ & Intermediate & $64(2-128)$ & 6 \\
\hline Bt 79 & Cottony & $6.10 \pm 0.91^{\#}$ & High & $2560(256-4096) *$ & 2 \\
\hline Bt 83 & Cottony & $5.34 \pm 0.7^{\#}$ & High & $256(128-256)^{*}$ & 2 \\
\hline Bt 84 & Cottony & $5.04 \pm 0.62^{\#}$ & High & $256(64-512)^{*}$ & 2 \\
\hline $\mathrm{Pb} 192$ & Glabrous & 0.0 & Avirulent & $1(0-16)$ & $>30$ \\
\hline $\mathrm{Pb} 265$ & Glabrous & $1.05 \pm 0.37^{\bullet}$ & Low & $128(16-256)$ & $>30$ \\
\hline $\mathrm{Pb} \mathrm{T}$ & Glabrous & $1.07 \pm 0.38 \bullet$ & Low & $128(128-128)$ & 5 \\
\hline
\end{tabular}

Antibody titer: results are expressed as median values with the range in parentheses; $*(\mathrm{p}<0.05)$ versus $\mathrm{Pb} 192$ (Kruskal-Wallis test). Log CFU/g lung tissue: $*(\mathrm{p}<0.05)$ versus $\mathrm{PbT}, \mathrm{Pb} 265$ and $\mathrm{Pb} 192 ;{ }^{*}(\mathrm{p}<0.01)$ versus $\mathrm{Bt56}, \mathrm{Bt32}, \mathrm{Pb} 18, \mathrm{~Pb} 18 \mathrm{~B} 6, \mathrm{PbT}, \mathrm{Pb} 265$ and $\mathrm{Pb} 192 ; \bullet(\mathrm{p}<0.05)$ versus $\mathrm{Pb} 192$ (ANOVA) 

with morphologic and genetic patterns. Rev. Inst. Med. trop. S. Paulo, 47(5): 257-262, 2005.

On the other hand, low virulent $\mathrm{Pb} 265, \mathrm{PbT}$, and non-virulent $\mathrm{Pb} 192$ isolates, having glabrous morphology, were recovered from lungs in low numbers (less than $1.07 \mathrm{log}$ CFUs/g) or not at all and, additionally, did not induce histopathologic lesions upon inoculation. These results suggest that both extreme phenotypes may be associated with fungal virulence, and, also, in connection with their record of in vitro sub-culturing. In general, fungi with glabrous morphology had been maintained by longer sub-culturing periods ( 5 to 30 years) than cottony ones ( 2 to 3 years). The exception occurred with $\mathrm{Pb} 18$ and Bt32 isolates, which presented intermediate virulence, lower fungal recovery (2.47 log CFUs/g or less) and cottony phenotype, maintained after long subculturing time (11 to 30 years). Thus, our results are in accordance to those obtained by SANO et al. ${ }^{25}$, showing that $P$. brasiliensis isolates with low in vitro subculture time and cottony morphology frequently present high virulence, while isolates with cottony phenotype, but long in vitro subculture period present lower or intermediate virulence. The phenomenon of in vitro virulence attenuation has also been described for other fungi that cause deep mycosis, such as Blastomyces dermatitidis ${ }^{3}$, and Cryptococcus neoformans ${ }^{9}$. Data from in vivo studies have revealed that virulence of $P$. brasiliensis isolates could be attenuated or even lost after in vitro long-term sub-cultivation ${ }^{4,14,22}$. This phenomenon could be reverted by re-isolation of the fungus from mice, independent of their susceptibility or resistance to paracoccidioidomycosis ${ }^{14}$.

Serum levels of specific antibodies to $P$. brasiliensis were significantly higher in animals infected with the highly virulent isolates and might well be associated with the antigenic fungal load in mouse tissues. These results appear similar to those in human disease, where high antibody levels are not associated with protection but with progressive fungal dissemination to various host organs $\mathrm{s}^{6,8}$.

RADP analysis of the ten P. brasiliensis isolates showed two main groups with $56 \%$ genomic identity, suggesting the variability of this fungus. Our results showed that $P$. brasiliensis recovered from patients from the same city or state were highly variable in contrast with the results obtained by CALCAGNO et al..$^{5}$ who found correlation between RAPD patterns and geographical region from which each fungal strain was isolated. Further studies on our RAPD grouping could be helpful ascertaining classification and fungal variability.

RAPD profile could discriminate some $P$. brasiliensis Bt pairs, such as Bt79 and Bt83 highly virulent with a similarity coefficient of about 96\%, and also $\mathrm{Pb} 192$ and $\mathrm{Pb} 265$ with $98.7 \%$ genetic similarity and low virulence. Each of these pairs had similar virulence degree in infected mice, similar colony morphology in PDA medium, with mice showing similar antibody titers. Our results suggest an association between RAPD patterns and degree of virulence in $P$. brasiliensis as previously suggested ${ }^{18}$. However, the RAPD technique did not discriminate between intermediate virulence strains such as $\mathrm{Pb} 18, \mathrm{~Pb} 18 \mathrm{~B} 6, \mathrm{Bt} 32$ and Bt56 which showed variability in their similarity coefficient. Also, Pb18 strain and Pb18B6, the isolate derived from $\mathrm{Pb} 18$ when recently isolated from severely infected C57B1/6 which exhibited only $88 \%$ of genetic similarity and the same capacities of infecting mice. These results are not in accordance with MOTTA et al..$^{20}$ who detected $100 \%$ similarity between $\mathrm{Pb} 18$ and its isolate derivatives (virulent, attenuated, and non-virulent) with different capacities of infecting susceptible mice. Thus, RAPD analyses could not discriminate strain virulence from one large group, but only between some pairs of $P$. brasiliensis strains in the subgroups studied.
In this study $\mathrm{Pb} 18$ and $\mathrm{Pb} 18 \mathrm{~B} 6$ showed no differences in virulence and morphology parameters, but some genetic variability. The genetic differences between $\mathrm{Pb} 18$ and its derivative $\mathrm{Pb} 18 \mathrm{~B} 6$ might be attributed to changes in the genomic DNA of the fungus required to adapt to the host's environment. Genetic changes or microevolution on standard strains have been suggested for other fungi such as $C$. neoformans ${ }^{9}, B$. dermatitidis $^{15}$ and $H$. capsulatum $^{2}$, and have been associated with phenotypic changes and loss of virulence.

Together, the results presented here demonstrate that $P$. brasiliensis isolates may vary in colony morphology and virulence associated with in vitro sub-culturing time. RAPD analysis showed some correlation with virulence and morphology of $P$. brasiliensis isolates. This technique allows detection of genetic variations between Brazilian isolates of $P$. brasiliensi $^{5,11,31}$. Differences in virulence between $P$. brasiliensis isolates may be dependent on factors that allow fungal growth under adverse conditions in the host. Elucidation of the factor which allows his fungus to overcome host defenses will lead to a better understanding of the pathogenesis of paracoccidioidomycosis.

\section{RESUMO}

\section{Perfil de virulência de dez isolados de Paracoccidioides brasiliensis. Associação com morfologia e padrão genético}

Dez isolados de $P$. brasiliensis foram avaliados em relação à patogenicidade por inoculação intravenosa em camundongos e associação com morfologia miceliana e padrão genético por amplificação genônica do DNA polimórfico (RAPD). A patogenicidade, avaliada por recuperação de fungos viáveis a partir de tecido pulmonar e por lesões histopatológicas em diferentes órgãos, mostrou que os isolados apresentaram quatro graus de virulência: alta virulência, virulência intermediária, baixa virulência e não virulência. A técnica de RAPD agrupou os isolados em dois grupos com 56\% de similaridade genética. Amostras com baixa virulência $\mathrm{Pb} 265$ ou não virulência $\mathrm{Pb} 192$ apresentaram morfologia glabra/cerebriforme e alta similaridade genética $(98,7 \%)$ quando comparadas com os outros isolados estudados. O mesmo foi observado com os isolados Bt79 e Bt83, que compartilharam $96 \%$ de semelhança genética, colônias cotonosas e alta virulência. Essa técnica pode discriminar apenas isolados com morfologia glabra da cotonosa e com alta e baixa virulência. Isolados com virulência intermediária como Pb18, Pb18B6, Bt32 e Bt54 mostraram variabilidade no coeficiente de similaridade, sugerindo que a técnica de RAPD permite mostrar variabilidade genética nessa espécie fúngica. $\mathrm{O}$ estudo do perfil de virulência das amostras de $P$. brasiliensis demonstrou que os dois fenótipos extremos de morfologia miceliana podem ser associados com a virulência do fungo e com o tempo de subcultivo in vitro. Assim, a análise de RAPD, utilizada em conjunto com aspectos de virulência, morfológicos e imunológicos pode ser considerada adequada para detectar diferenças entre isolados de $P$. brasiliensis.

\section{ACKNOWLEDGEMENTS}

We thank Ana Yamaguishi Ciampi and Ayako Sano for technical assistance and critical suggestions about the work. This work was supported by CNPq and CAPES. 


\section{REFERENCES}

1. AUFAUVRE-BROWN, A.; COHEN, J. \& HOLDEN, D.W. - Use of randomly amplified polymorphic DNA markers to distinguish isolates of Aspergillus fumigatus. J. clin. Microbiol., 30: 2991-2993, 1992.

2. BERLINER, M.D. - Primary subcultures of Histoplasma capsulatum. I. Macro and micromorphology of the mycelial phase. Sabouraudia, 6: 111-118, 1968.

3. BRASS, C.; VOLKMANN, C.M.; PHILPOTT, D.E. et al. - Spontaneous mutant of Blastomyces dermatitidis attenuated in virulence for mice. Sabouraudia, 20: 145$158,1982$.

4. BRUMMER, E.; RESTREPO, A.; HANSON, L.H. \& STEVENS, D.A. - Virulence of Paracoccidioides brasiliensis: the influence of in vitro passage and storage. Mycopathologia (Den Haag), 109: 13-17, 1990.

5. CALCAGNO, A.M.; NIÑO-VEGA, G.; SAN-BLAS, F. \& SAN-BLAS, G. - Geographic discrimination of Paracoccidioides brasiliensis strains by randomly amplified polymorfic DNA analysis. J. clin. Microbiol., 36: 1733-1736, 1998.

6. CAMARGO, Z.P. \& CANO, L.H. - Humoral immunity. In: FRANCO, M.F.; LACAZ, C.S.; RESTREPO, A. \& DEL NEGRO, G., ed. Paracoccidioidomycosis. Boca Raton, CRC Press, 1994. p. 187-197.

7. CASALS, J.B. - Tablet sensitivity testing of pathogenic fungi. J. clin. Path., 32: 719$722,1979$.

8. FRANCO, M. - Host-parasite relationship in paracoccidioidomycosis, J. med. vet. Mycol., 25: 5-18, 1986.

9. FRANZOT, S.P.; MUKHERJEE, J.; CHERNIAK, R. et al. - Microevolution of a standard strain of Cryptococcus neoformans resulting in differences in virulence and other phenotypes. Infect. Immun., 1: 89-97, 1998.

10. GRATTAPAGLIA, D. \& SEDEROFF, R. - Genetic linkage maps of Eucalyptus grandis and Eucalyptus urophylla using a pseudo-testcross: mapping strategy and RAPD markers. Genetics, 137: 1121-1137, 1994.

11. HAHN, R.C.; MACEDO, A.M.; FONTES, C.J. et al. - Randomly amplified polymorphic DNA as a valuable tool for epidemiological studies of Paracoccidioides brasiliensis. J. clin. Microbiol., 41: 2849-2854, 2003.

12. KASHINO, S.S.; CALICH, V.L.G.; BURGER, E. \& SINGER-VERMES, L.M. - In vivo and in vitro characteristics of six Paracoccidioides brasiliensis strains. Mycopathologia (Den Haag), 92: 173-178, 1985.

13. KASHINO, S.S.; CALICH, V.L.G.; SINGER-VERMES, L.M.; ABRAHAMSOHN, P.A \& BURGER, E. - Growth curves, morphology and ultrastructure of ten Paracoccidioides brasiliensis isolates. Mycopathologia (Den Haag), 99: 119-128, 1987.

14. KASHINO, S.S.; SINGER-VERMES, L.M; CALICH, V.L.G. \& BURGER, E. - Alteration in the pathogenicity of Paracoccidioides brasiliensis isolates do not correlative with its in vitro growth. Mycopathologia (Den Haag), 111: 173-180, 1990.

15. KAUFMAN, L.; STANDARD, P.G.; WEEKS, R.J. \& PADHYE, A.A. - Detection of two Blastomyces dermatitidis serotypes by exoantigen analysis. J. clin. Microbiol., 18: 110-114, 1983.

16. LOWRY, O.H.; ROSENBROUGH, N.J.; FARR, A.L. \& RANDALL, R.J. - Protein measurement with folin phenol reagent. J. biol. Chem., 193: 265-275, 1951.

17. MENDES-GIANNINI, M.J.S.; CAMARGO, M.E.; LACAZ, C.S. \& FERREIRA, A.W. Immunoenzymatic absorption test for serodiagnosis of paracoccidioidomycosis. J. clin. Microbiol., 20: 103-108, 1984.

18. MOLINARI-MADLUM, E.E.; FELIPE, M.S.S. \& SOARES, C.M.A. - Virulence of Paracoccidioides brasiliensis can be correlated to groups defined by random amplified polymorphic DNA analysis. Med. Mycol., 37: 269-276, 1999.
19. MONDON, P.; THÉLU, J.; LEBEU, B.; AMBROISE-THOMAS, P. \& GRILLOT, R. Virulence of Aspergillus fumigatus strains investigated by random amplified polymorphic DNA analysis. J. med. Microbiol., 42: 299-303, 1995.

20. MOTTA, T.R.; MOREIRA-FILHO, C.A.; MENDES, R.P. et al. - Evaluation of DNA polymorphisms amplified by arbitrary primers (RAPD) as genetically associated elements to differentiate virulent and non-virulent Paracoccidioides brasiliensis isolates. FEMS Immunol. med. Microbiol., 33: 151-157, 2002.

21. PAN, S. \& COLE, G.T. - Electrophoretic karyotypes of clinical isolates of Coccidioides immitis. Infect. Immun., 60: 4872-4880, 1992.

22. PERAÇOLI, M.T.S.; SUGIZAKI, M.F.; MENDES, R.P.; NAIFF, R. \& MONTENEGRO, M.R. - Paracoccidioides brasiliensis isolated from armadillos is virulent to Syrian hamsters. Mycopathologia (Den Haag), 148: 123-130, 1999.

23. ROHLF, F.J. - NTSYS-pc Version 1.7 Numerical Taxonomy and Multivariate. New York, Analysis System Exeter Publ., 1992.

24. SAN-BLAS, G. \& SAN-BLAS, F. - Paracoccidioides brasiliensis: cell wall structure and virulence. Mycopathologia (Den Haag), 62: 77-86, 1977.

25. SANO, A.; TANAKA, R.; NISHIMURA, K. et al. - Characteristics of 17 Paracoccidioides brasiliensis isolates. Mycoscience, 38: 117-122, 1997.

26. SANO, A.; TANAKA, R.; YOKOYOMA, K. et al. - Comparison between human and armadillo Paracoccidioides brasiliensis isolates by random amplified polymorphic DNA analysis. Mycopathologia (Den Haag), 143: 165-169, 1999.

27. SINGER-VERMES, L.M.; BURGER, E.; CALICH, V.L.G. et al. - Pathogenicity and immunogenicity of Paracoccidioides brasiliensis isolates in the human disease and in an experimental murine model. Clin. exp. Immunol., 97: 113-119, 1994.

28. SINGER-VERMES, L.M.; CIAVAGLIA, M.C.; KASHINO, S.S.; BURGER, E. \& CALICH, V.L.G. - The source of the growth-promoting factor (s) affects the plating efficiency of Paracoccidioides brasiliensis. J. med. vet. Mycol., 30: 261-264, 1992.

29. SINGER-VERMES, L.M.; CALDEIRA, C.B.; BURGER, E. \& CALICH, L.G. Experimental murine paracoccidioidomycosis: relationship among the dissemination of the infection, humoral and cellular immune responses. Clin. exp. Immunol., 94: 75-79, 1993.

30. SOARES, A.M.; CALVI, S.A.; PERAÇOLI, M.T. et al. - Modulatory effect of prostaglandins on human monocyte activation for killing of high- and low-virulence strains of Paracoccidioides brasiliensis. Immunology, 102: 480-485, 2001.

31. SOARES, C.M.; MADLUN, E.E.; SILVA, S.P.; PEREIRA, M. \& FELIPE, M.S. Characterization of Paracoccidioides brasiliensis isolates by random amplified polymorphic DNA analysis. J. clin. Microbiol., 33: 505-507, 1995.

32. SOLL, D.R. - High-frequency switching in Candida albicans. Clin. Microbiol. Rev., 5: 183-203, 1992

33. WANKE, B. \& LONDERO, A,T. - Epidemiology and paracoccidioidomycosis infection In: FRANCO, M.; LACAZ, C.S.; RESTREPO-MORENO, A. \& DEL NEGRO, G., ed. Paracoccidioidomycosis. Boca Raton, CRC Press, 1994. p. 109-120.

34. WILLIAMS, J.G.K.; KUBELIK, A.R.; LIVAK, K.J.; RAFALSKI, J.Á. \& TINGERY, S.V. - DNA polymorphisms amplified by arbitrary "primers" are useful as genetic markers. Nucleic Acids Res., 18: 6531-6535, 1990.

35. WOODS, J.P.; KERSULYTE, D.; GOLDMAN, W.E. \& BERG, D.E. - Fast DNA isolation from Histoplasma capsulatum: methodology for arbitrary primer polymerase chain reaction- based epidemiological and clinical studies. J. clin. Microbiol., 31: 463464, 1993.

Received: 15 March 2005

Accepted: 12 July 2005 